\title{
Preliminary observations on artificial fecundation, hatching and developmental stages of embryo and larvae of the Indian shad Tenualosa ilisha (Hamilton, 1822)
}

\author{
D. N. CHATTOPADHYAY, A. CHAKRABORTY, P. K. RAY AND P. JAYASANKAR* \\ ICAR-Central Institute of Freshwater Aquaculture, Field station of Rahara Regional Research Centre \\ Santalpara, P. O. Kalyani - 741 235, Nadia District, West Bengal, India \\ *ICAR-Central Marine Fisheries Research Institute, Ernakulam North, P. O., Kochi - 682018 , Kerala, India \\ e-mail: deb_cifa@yahoo.com
}

\section{ABSTRACT}

\begin{abstract}
Hilsa Tenualosa ilisha (Hamilton, 1822), one of the important commercial fish species in South Asian countries has received much attention for its conservation through captive breeding and seed production. The present study attempted to breed the fish by dry stripping in river Hooghly. Eggs were incubated at 22.8 and $28.3^{\circ} \mathrm{C}$ temperatures in estuarine, pond and tap water. The hatching rate recorded was higher $(\mathrm{p}<0.05)$ in pond water $(88-96 \%)$ compared to estuarine $(70-76 \%)$ and tap water $(72-74 \%)$ at both temperatures tested. Incubation period (19-22 h) and hatching rates in the three water media were not influenced by tested temperatures. Hourly changes in embryonic development till hatching and daily changes in 0-10 day old larvae are described in this paper.
\end{abstract}

Keywords: Artificial fecundation, Embryonic development, Hatching, Hilsa, Tenualosa ilisha

The Indian shad Tenualosa ilisha (Hamilton, 1822), is distributed in coastal areas, estuaries and freshwater rivers of several countries bordering Bay of Bengal, Indian Ocean, Persian Gulf and Arabian Sea including India, Bangladesh, Pakistan, Indonesia, Sumatra, Myanmar, Kuwait, Iraq, Iran, Sri Lanka and Vietnam where the species contribute to important commercial fishery (Pillay and Rosa, 1963; Jaffri and Melvin, 1988). In India, the Hooghly Estuary is the major ground where the fish migrate from Bay of Bengal for breeding and nurturing young ones. In recent years, the natural stock of T. ilisha in Hooghly Estuary has been drastically declined with a consequent increase in demand and price of the fish. Total marine landings of hilsa in India were 74916; 22210 and 17830 t during 2010, 2011 and 2012 respectively (DADF, 2014).

Realising the importance of the species and to reinstate the hilsa fishery in the natural ecosystems, there is an urgent need for its propagation through culture, captive breeding and implementation of appropriate conservation methods. Since hilsa is a euryhaline anadromous migratory fish, a thorough knowledge on the breeding habits and embryonic as well as larval developmental stages is of utmost importance to develop hatchery technology. Standard protocols for artificial fecundation of hilsa have not yet been developed due to several limitations. The availability of the number of freely oozing females is very rare (hardly 2-3 in a year) in the landings. At the same time, the quantity of milt that can be collected from males when such females are caught is also very less (hardly 1-2 drops per male). Besides, the fish are caught by gillnet from the river, which render heavy stress on the fish and as a result, they die immediately or remain alive only for 10-20 min in spite of best efforts to keep them alive for longer periods for stripping. Sometimes, milting males are available but not the freely oozing females and vice versa. Therefore, captured fish of one sex die before the other sex is available. Moreover, hilsa migrates from sea to river during their breeding season (twice in a year i.e., February to March and September to October) particularly during the period of new moon and full moon for 3-4 days when the level of high tide increases. Therefore, hilsa is available in the estuary only for a short period and the chances of getting fully mature females and males are extremely scarce.

The previous studies on breeding, egg characteristics and embryonic developmental stages of hilsa (Southwell and Prashad, 1918; Kulkarni, 1950; Jones and Menon 1951; Motwani et al., 1957; Karamchandani 1961; Panicker, et al., 1982; De and Sen, 1986) reveal that there are several gaps in proper understanding of the breeding of fish. Digital photomicrographs of embryonic and larval stages of the fish are lacking, though camera lucida drawings of some stages are available (Kulkarni, 1950; 
Jones and Menon 1951; De and Sen, 1986), which fails to explain the detailed developmental processes. Reports on success in dry stripping and effects of temperature and water from various sources on the incubation, hatching and growth of larvae are also lacking. Maintenance of standard physico-chemical qualities of water are essential pre-requisites for success in egg fertilisation, hatching and development of embryo as well as larva. In earlier studies, egg fertilisation, incubation and larval rearing of hilsa were done in river, reservoir, pond, $1 \%$ normal saline and tap water but the water quality parameters were either not reported (Kulkarni, 1950; Jones and Menon, 1951; Motwani et al., 1957; Karamchandani, 1961; Malhotra et al., 1969; Mathur et al., 1974; Panicker et al., 1982) or only a few parameters were studied leaving some other relevant parameters uninvestigated (Malhotra et al. 1970; De and Sen, 1986; Sen et al., 1990). The comparative evaluation of hatching from same egg batch in different sources of water having different water quality parameters has not been reported so far.

Considering all these information, the present study was undertaken to investigate the hatching rates of fertilised eggs in three different sources of water viz., estuarine, pond and tap water maintained at two different temperatures under laboratory condition so that better sources of water with desirable water qualities can be evaluated for better hatching success and also to generate information on the options for using different sources of water for hatching purpose where river water is not accessible. Attempts were also made to document and elucidate the details of changes occurring during embryonic as well as larval developmental stages of hilsa by digital photomicrography, which is required for development of cultured hilsa and to recognise similar stages available in river/estuary so that specific conservation strategy can be developed in future.

Artificial fecundation and fertilisation of eggs of hilsa was conducted by dry stripping in the Hooghly Estuary at Godakhali, South 24 parganas, West Bengal, India $\left(24^{\circ} 49^{\prime} 18^{\prime \prime} \mathrm{N} ; 88^{\circ} 21^{\prime} 54^{\prime \prime}\right.$ E) on 22 September, 2013 ( $3^{\text {rd }}$ day after full moon) at $1600 \mathrm{hrs}$. The brood male fishes $(256.33 \pm 11.69 \mathrm{~mm} / 189.93 \pm 32.57 \mathrm{~g}, \mathrm{~N}=3)$ with freely oozing white coloured milt and fully mature female fish $(370 \mathrm{~mm} / 636.3 \mathrm{~g}, \mathrm{~N}=1)$ with freely oozing yellow coloured eggs were captured by gillnet from the Hooghly Estuary and selected for stripping. The female and male brood fishes died respectively at 45 and $25 \mathrm{~min}$ before stripping. In dry stripping, water from the body surface of female and male was wiped off using tissue paper so that no single drop of water got mixed with egg and milt during stripping. The eggs were stripped out with gentle hand pressure on the abdomen and were spread over a dry steel tray. This was immediately followed by stripping out milt from males. Milt was directly spread over the eggs and mixed thoroughly with clean and sterile bird feather. The activation of milt for fertilisation was initiated by sprinkling estuarine water (pre-settled and filtered with bolting silk) over the milt-egg mixture. Immediately after sprinkling water, the tray was gently moved sidewise for a min so that all the eggs and sperms came in contact with each other for proper fertilisation. The eggs were thoroughly washed with estuary water several times prior to transferring for incubation. The experiment was conducted as per the animal ethical norms of the Institute.

The study on egg incubation period and hatching rate was done in the laboratory situated near the river. For experimental purposes, the fertilised eggs were incubated in glass petridish in three different sources of freshwater (estuary, pond and tap water) eatch maintained at two different temperatures $\left(22.8 \pm 0.04^{\circ} \mathrm{C}\right.$ and $\left.28.3 \pm 0.06^{\circ} \mathrm{C}\right)$. Five replicates were maintained for each set of environmental condition. Ten fertilised eggs were kept in each petridish having $500 \mathrm{ml}$ of water. When the eggs were transferred to the petridish, the temperature of each source of water was kept similar $\left(31.3^{\circ} \mathrm{C}\right)$ in which the eggs were fertilised to ensure that eggs were not exposed to temperature shock.

For examination of embryonic developmental stages, the fertilised eggs were also kept separately in five glass petridishes each having $500 \mathrm{ml}$ of estuarine water and 10 fertilised eggs, which were incubated at $28.3^{\circ} \mathrm{C}$ temperature. The eggs from these petridishes were randomly collected at one hour interval until hatching and the embryonic developmental stages were observed immediately under a microscope.

The hatched out larvae were further incubated in glass aquaria (water volume 45 1) under laboratory condition with continuous aeration system in ambient water temperature $\left(28.03 \pm 0.11^{\circ} \mathrm{C}\right), \mathrm{pH} \quad(8.4 \pm 0.01)$, DO (7.87 $\left.\pm 0.1 \mathrm{mg} \mathrm{l}^{-1}\right)$, free $\mathrm{CO}_{2}\left(0 \mathrm{mg} \mathrm{l}^{-1}\right)$, alkalinity $\left(83.43 \pm 2.21 \mathrm{mg} \mathrm{l}^{-1}\right)$, hardness $\left(104.13 \pm 1.14 \mathrm{mg} \mathrm{l}^{-1}\right)$, salinity $\left(0.11 \pm 0.001 \mathrm{~g} \mathrm{l}^{-1}\right)$, conductivity $\left(188.21 \pm 5.35 \mu \mathrm{S} \mathrm{cm}^{-1}\right)$ and TDS $\left(134.5 \pm 3.8 \mathrm{mg} \mathrm{l}^{-1}\right)$ and their developmental stages were studied under microscope at $24 \mathrm{~h}$ interval up to 10 days.

At every $6 \mathrm{~h}$ interval, $70 \%$ water from each petridish was replenished with respective sources of water which was kept separately at two tested temperatures in plastic buckets with continuous aeration system. The water quality parameters were recorded at $6 \mathrm{~h}$ interval following the methods of APHA (1995) and using a multi-parameter PCSTEST35 sensor (Eutech, Singapore). Measurement of egg diameter and larval length were taken randomly from 
30 samples using ocular micrometer and digital callipers. Different parameters in artificial fecundation were calculated using the following formulae:

(1) Net weight of stripped eggs $(\mathrm{g})=$ Weight of female before stripping $(\mathrm{g})$ - Weight of female after stripping $(\mathrm{g})$.

(2) Total weight of eggs (g) = Net weight of stripped eggs (g) + Weight of remaining eggs in the ovary $(\mathrm{g})$.

(3) No. of eggs stripped (estimated) $=$ Net weight of stripped eggs $(\mathrm{g})$ x No. of eggs $\mathrm{g}^{-1}$ of egg mass.

(4) Relative fecundity (Total number of eggs released $\mathrm{kg}^{-1}$ female $)=$ Total number of stripped eggs / Total body weight of the female $(\mathrm{kg})$.

(5) Total number of eggs in the ovary (estimated) $=$ Total weight of eggs ( $\mathrm{g}) \times$ No. of eggs $\mathrm{g}^{-1}$ egg mass

(6) Total number of eggs kg-1 body weight of female (estimated) $=$ Total number of eggs in the ovary x $1000 /$ Weight of female before stripping $(\mathrm{g})$

(7) Fertilisation (\%) = Number of fertilised eggs x $100 /$ Total number of eggs counted

(8) No. of fertilised eggs (estimated) $=$ No. of eggs stripped $\mathrm{x}$ Fertilisation (\%) / 100

\section{Statistical analysis}

Statistical analysis of the data was done using SPSS 10.0 for windows (SPSS Inc., Chicago, IL, USA). For test of significance, multiple comparisons of post hoc test (LSD) in one-way ANOVA were used. Results are presented as mean $\pm \mathrm{SE}$ (standard error).

The water quality parameters maintained during fertilisation were: temperature $-31.3^{\circ} \mathrm{C}, \mathrm{pH}-7.5$, dissolved oxygen (DO) - $6.4 \mathrm{mg} \mathrm{l}^{-1}$, free carbon di-oxide $\left(\mathrm{CO}_{2}\right)$ - $0 \mathrm{mg} \mathrm{l}^{-1}$, alkalinity - $94 \mathrm{mg} \mathrm{l}^{-1}$, hardness - 138 $\mathrm{mg} \mathrm{l}^{-1}$, salinity - $0.15 \mathrm{~g} \mathrm{l}^{-1}$, conductivity $-303 \mu \mathrm{S} \mathrm{cm}^{-1}$ and total dissolved solids (TDS) - $214 \mathrm{mg} \mathrm{l}^{-1}$. By dry stripping, 93\% fertilisation was obtained (Table 1). Swelling of eggs started just after sprinkling and adding water on the mixture of eggs and milt. The fertilised eggs were spherical and transparent having yellowish yolk with numerous oil globules. The unfertilised eggs $(1.80 \pm 0.007 \mathrm{~mm}$ in dia) were having whitish yolk which could be easily differentiated from the crystal like yolk of fertilised eggs. Fully swelled fertilised eggs $(2.10 \pm 0.006$ $\mathrm{mm}$ in dia) were observed after 45 min of stripping. Egg membrane was single layered as observed through microscopic study.

Table 2 presents the hatching rate (\%) of hilsa eggs under different environmental conditions in the laboratory. The eggs hatched within 19-22 $\mathrm{h}$ of fertilisation in all sets of environmental conditions i.e., irrespective of water media and temperatures. The
Table 1. Details of artificial fecundation of hilsa

\begin{tabular}{ll}
\hline Parameters & Value \\
\hline Weight of female before stripping (g) & 636.3 \\
Weight of female after stripping (g) & 582.5 \\
Net weight of stripped eggs (g) & 53.8 \\
Weight of remaining eggs in the ovary (g) & 56.2 \\
Total weight of eggs in female (g) & 110 \\
No. of egg $\mathrm{g}^{-1}$ of egg mass & 4511 \\
No. of eggs stripped (estimated) & $2,42,692$ \\
Relative fecundity (no. of eggs released $\mathrm{kg}^{-1}$ & $3,81,411$ \\
female) & \\
Total number of eggs in the ovary of & $4,96,210$ \\
female (estimated) & \\
Total number of eggs kg ${ }^{-1}$ body weight of & $7,79,836$ \\
female (estimated) & \\
Fertilisation (\%) & 93 \\
No. of fertilised eggs (estimated) & 225704 \\
Number of hatchlings produced (estimated) & 10857 \\
\hline
\end{tabular}

hatching rate in three different water media was $74-96 \%$ at the lower temperature $\left(22.8 \pm 0.04^{\circ} \mathrm{C}\right)$ and $70-88 \%$ at the higher temperature $\left(28.3 \pm 0.06^{\circ} \mathrm{C}\right)$. The hatching rate was significantly higher $(\mathrm{p}<0.05)$ in pond water $(88-96 \%)$ as compared to estuarine (70-76\%) or tap water $(72-74 \%)$ in both tested temperatures. The hatching rates in same water at different tested temperatures did not vary significantly.

Hourly changes in embryonic development till hatching are described in Table 3 and Fig. 1. Before hatching, the larvae slowly move towards egg membrane without showing any apparent movement of body or tail. At this stage whole body remains straight except the caudal fin which remains folded resting on the egg membrane. Finally the head region of the larva touch the egg membrane and after 17-19 s larva comes out of the egg by penetrating the egg membrane. When the head region of the larva comes in contact with egg membrane the caudal fin unfolds and becomes straight.

The daily changes in larvae (up to 10 days) are described in Table 4 and Fig. 2. Larval length from 0-10 days is given in Fig. 3, where 0-day represents the newly hatched larvae. Immediately after hatching, the larvae remain static for 25-33 s and suddenly start moving in circular path keeping the yolk sac upside. They move their tail vigorously. Intermittently the larvae take rest for a few seconds and move again.

The fertilisation rate in dry stripping method in the present study was higher (93\%) than that of wet stripping method (30-50, 70-90 and 90\% as reported by Malhotra et al., 1969 and Sen et al., 1990). There are some advantages of dry stripping over wet stripping. The 
Table 2. Hatching of hilsa eggs under different environmental conditions

\begin{tabular}{llll}
\hline \multirow{2}{*}{ Parameters } & \multicolumn{2}{l}{ Egg incubation in petridish } \\
\cline { 2 - 4 } & Estuarine water & Pond water & Tap water $^{*}$ \\
\hline Water quality & & & $7.3 \pm 0.004$ \\
\hline $\mathrm{pH}$ & $7.5 \pm 0.003$ & $7.8 \pm 0.006$ & $8.4 \pm 0.08$ \\
$\mathrm{DO}\left(\mathrm{mg} \mathrm{l}^{-1}\right)$ & $7.95 \pm 0.05$ & $8 \pm 0.14$ & Nil \\
Free $\mathrm{CO}_{2}\left(\mathrm{mg} \mathrm{l}^{-1}\right)$ & $\mathrm{Nil}$ & $\mathrm{Nil}$ & $98 \pm 0.82$ \\
Alkalinity $\left(\mathrm{mg} \mathrm{l}^{-1}\right)$ & $94 \pm 0.82$ & $255 \pm 0.5$ & $140 \pm 1.71$ \\
Hardness $\left(\mathrm{mg} \mathrm{l}^{-1}\right)$ & $138 \pm 0.82$ & $0.59 \pm 0.48$ & $0.13 \pm 0.63$ \\
Salinity $\left(\mathrm{g} \mathrm{l}^{-1}\right)$ & $0.15 \pm 0.75$ & $1205 \pm 0.48$ & $258 \pm 0.09$ \\
Conductivity $\left(\mu \mathrm{S} \mathrm{cm}^{-1}\right)$ & $303 \pm 0.04$ & $855 \pm 0.11$ & $183 \pm 0.11$ \\
TDS $\left(\mathrm{mg} \mathrm{l}^{-1}\right)$ & $214 \pm 0.24$ & & $74 \pm 2.45^{\mathrm{a}}$ \\
\hline Hatching rate $(\%)$ at & & $96 \pm 2.45^{\mathrm{b}}$ & $72 \pm 3.74^{\mathrm{a}}$ \\
\hline $22.8 \pm 0.04^{\circ} \mathrm{C}$ & $76 \pm 5.1^{\mathrm{a}}$ & $88 \pm 2^{\mathrm{b}}$ & \\
$28.3 \pm 0.06^{\circ} \mathrm{C}$ & $70 \pm 3.16^{\mathrm{a}}$ & & \\
\hline
\end{tabular}

Values are expressed as mean $\pm \mathrm{SE}$, where $\mathrm{n}=5$ and 4 for hatching rate and water qualities, respectively

a,b Values with different superscripts in a row and column differ significantly $(p<0.05)$

*Supplied from Hooghly estuary water treatment plant, Godakhali, West Bengal, India

Table 3. Characteristics features of hourly developmental stages of hilsa embryo till hatching

\begin{tabular}{|c|c|}
\hline Hours after fertilisation & Characteristics \\
\hline 1 & Initiation of cell division is observed at the periphery of yolk \\
\hline 2 & Blastodermal cap appears as a thin layer over the yolk \\
\hline 3 & Embryo looks crescent shaped and attains morula stage \\
\hline 4 & Further proliferation of cells leads to blastula stage \\
\hline 5 & Embryonic mass covers one third of the yolk indicating initiation of gastrulation process \\
\hline 6 & Almost $50 \%$ of epiboly is completed \\
\hline 7 & A circular embryonic germ ring is visible on the periphery of blastodermal rim \\
\hline 8 & Germ ring becomes thicker \\
\hline 9 & Embryonic shield is formed at a particular area of the germ ring \\
\hline 10 & Almost $75 \%$ epiboly is completed \\
\hline 11 & $\begin{array}{l}\text { Tail and head buds are clearly visible; head bud is wider than tail bud. The number of oil globules is } \\
\text { reduced with unequal sizes }\end{array}$ \\
\hline 12 & The tail end develops faster than head \\
\hline 13 & Pronounced head and tail appear \\
\hline 14 & Single large oil globule occupies the centre of yolk while numerous small oil globules concentrate over it \\
\hline 15 & Most of the small oil globules are fused to form two large oil globules. Optic vesicle is visible \\
\hline 16 & $\begin{array}{l}\text { Tail looks like a hook. Single conspicuous large oil globules with } 7-8 \text { small ones are visible Optic and } \\
\text { auditory vesicles are clearly visible }\end{array}$ \\
\hline 17 & $\begin{array}{l}\text { Embryo with large tail looks like a coma. Jerking of tail by muscular contraction and relaxation is } \\
\text { observed at an average interval of } 6 \mathrm{~s} \text { for duration of } 1-3 \mathrm{~s}\end{array}$ \\
\hline 18 & Tail is more or less straight. Well marked head is visible. One large and a few small oil globules are seen \\
\hline 19 & Heart pulsation is observed. The larva is ready to hatch \\
\hline
\end{tabular}

micropyle of egg (the entry point of the sperm) closes when water enters through micropyle and mixes with the perivitelline fluid of egg. Obviously, in the dry method, the micropyle remains open longer than in wet method of stripping. Therefore, more time is available for stripping out eggs and milt from several females and males at a time for fertilisation. Lal et al. (1999) have reported that spermatozoa of $T$. ilisha remain motile only for
40-50 s after activation by mixing river water with fresh milt. Small duration of sperm motility probably support further in favour of conducting dry stripping for getting more fertilisation than wet stripping. Since hilsa is highly fecund fish, $3 \%$ higher fertilisation rate as obtained by dry stripping in the present study than that of wet stripping done by others, increased the total number of available fertilised eggs. 


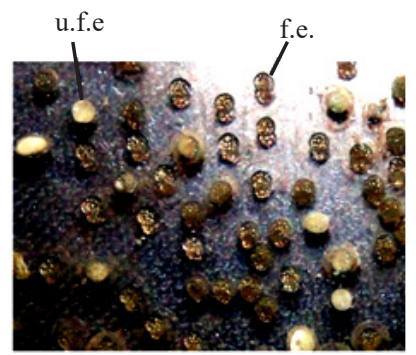

(a)

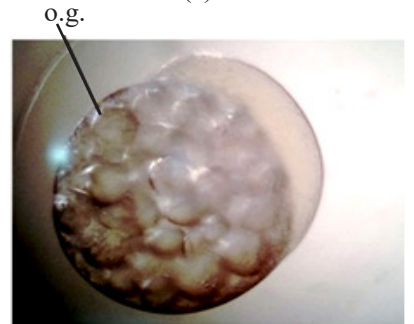

(e)

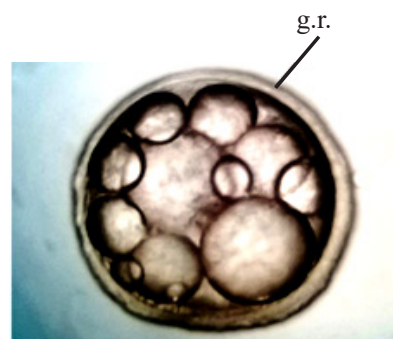

(i)

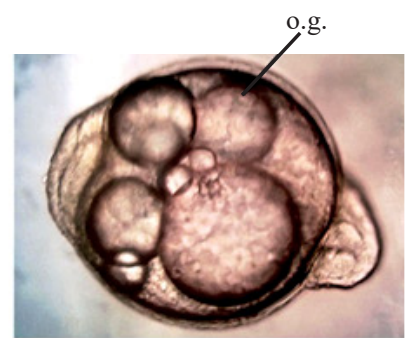

$(\mathrm{m})$

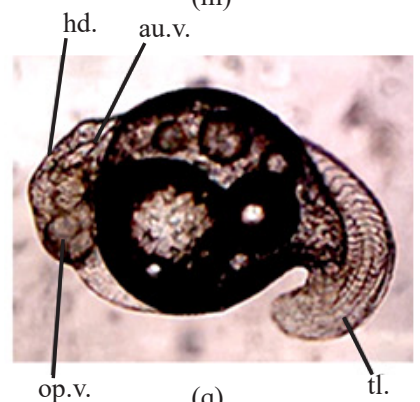

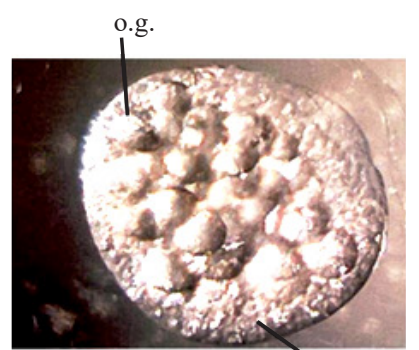

(b)

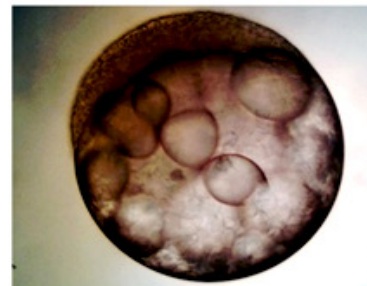

(f)

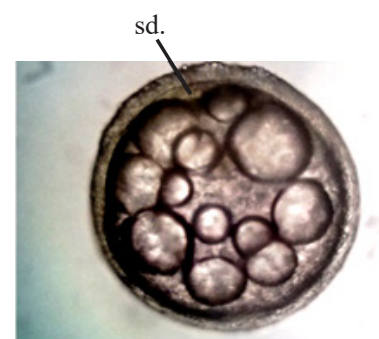

(j)

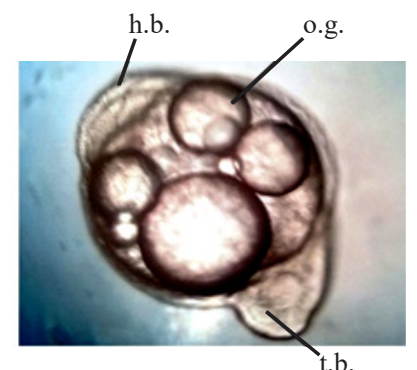

(n)

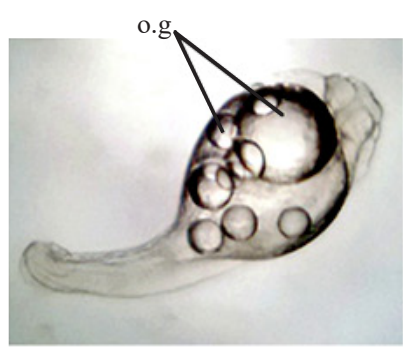

(r)

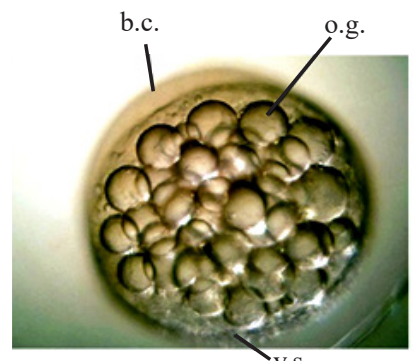

(c)

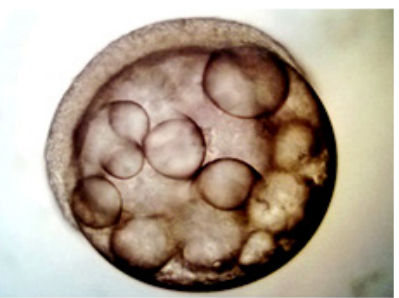

(g)

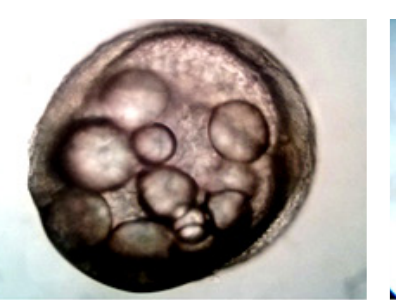

(k)

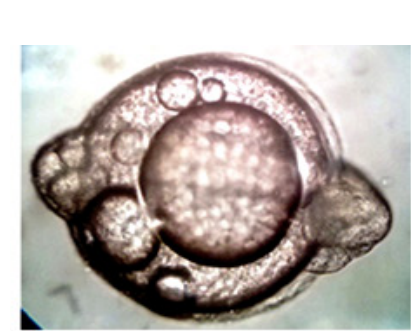

(o)

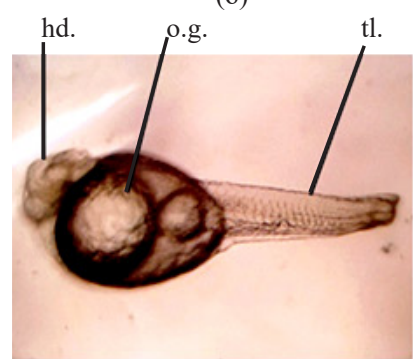

(s)

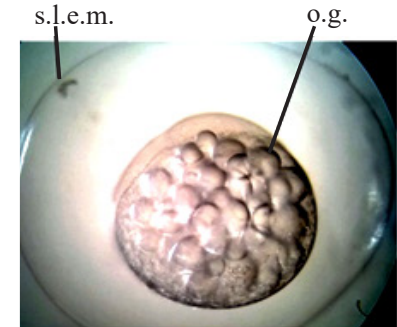

(d)

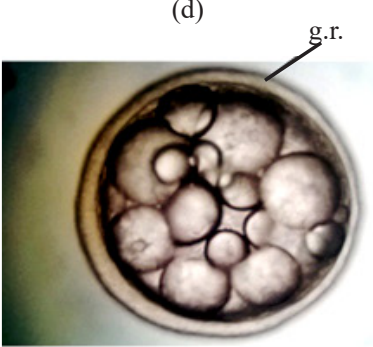

(h)

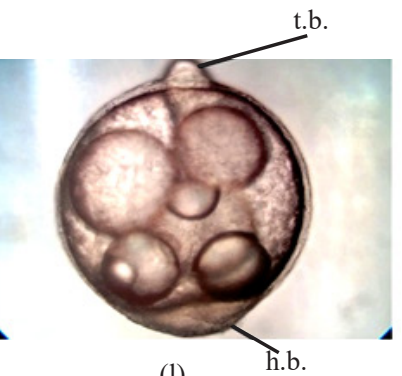

(1)

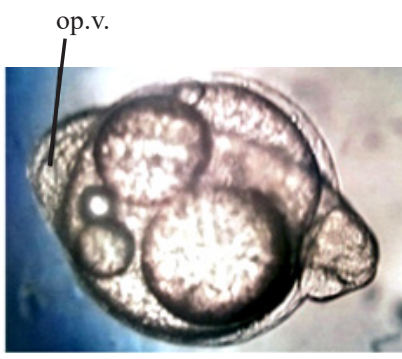

(p)

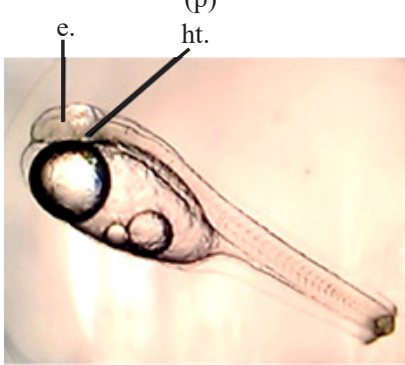

(t)

Fig. 1. Eggs and embryonic developmental stages (1-19 h after fertilisation) of hilsa (Tenualosa ilisha). a - fertilised and unfertilised eggs; $\mathrm{b}$ - egg after $1 \mathrm{~h}$; c - egg after $2 \mathrm{~h} ; \mathrm{d}$ - morula stage after $3 \mathrm{~h}$; e - blastula stage after $4 \mathrm{~h}$; f - early gastrula after $5 \mathrm{~h} ; \mathrm{g}$ - about $50 \%$ epiboly after $6 \mathrm{~h}$; $\mathrm{h}$ - visible germ ring after $7 \mathrm{~h} ; \mathrm{i}$ - germ ring after $8 \mathrm{~h} ; \mathrm{j}$ - embryonic shield formation after $9 \mathrm{~h} ; \mathrm{k}-75 \%$ epiboly after $10 \mathrm{~h} ; 1$ - bud formation after $11 \mathrm{~h} ; \mathrm{m}$ - embryo after $12 \mathrm{~h} ; \mathrm{n}$ - embryo after $13 \mathrm{~h} ; \mathrm{o}$ - embryo after $14 \mathrm{~h} ; \mathrm{p}$ - embryo after $15 \mathrm{~h} ; \mathrm{q}$ - embryo after $16 \mathrm{~h}$; $\mathrm{r}$ - twitching starts after $17 \mathrm{~h} ; \mathrm{s}$ - embryo after $18 \mathrm{~h} ; \mathrm{t}$ - embryo ready for hatching after $19 \mathrm{~h}$ (au.v. - auditory vesicle; b.c. - blastodermal cap; e. - eye; f.e. - fertilised egg; g.r. - germ ring; hd. - head; h.b. - head bud; ht. - heart; o.g. - oil globule; op.v. - optic vesicle; sd. - shield; s.l.e.m. - single layered egg membrane; t.b. - tail bud; tl. - tail; u.f.e. - unfertilised egg; y.s. - yolk segment). 
Table 4. Characteristics features of larvae of hilsa at different days

\begin{tabular}{|c|c|}
\hline Age of larva (day) & Characteristics \\
\hline $0 *$ & Body is transparent. Unpigmented eye with circular lens appears. Heart pulsation is observed \\
\hline 1 & $\begin{array}{l}\text { Yolk sac contains three small and a large oil globule. The caudal fin lobe and rudiments of pectoral fin } \\
\text { buds appear }\end{array}$ \\
\hline 2 & $\begin{array}{l}\text { Yolk sac contains two small and a large oil globules. Dark large eyes, pectoral fin buds and caudal fin } \\
\text { are clearly visible. Gut and anus appears. Movement of opercula is observed. Rudiments of gills and jaw } \\
\text { formation are observed }\end{array}$ \\
\hline 3 & $\begin{array}{l}\text { Yolk sac contains single large oil globule. Caudal fin is tapered at the end. Heart is well developed. Eyes } \\
\text { look bluish with black pupil at the centre. Alimentary canal appears as a fine tube }\end{array}$ \\
\hline 4 & $\begin{array}{l}\text { Yolk sac is reduced in size. Caudal fin is broad and rounded with a few fin rays. Mouth movement is } \\
\text { observed. The larvae move at the bottom }\end{array}$ \\
\hline 5 & $\begin{array}{l}\text { Movement of larvae is fast and rush towards the area where rotifers are Introduced.Caudal fin rays are } \\
\text { well developed }\end{array}$ \\
\hline 6 & Larvae are long and slender with yolk sac. Pectoral fin is prominent \\
\hline 7 & Larvae with small yolk sac moves very fast \\
\hline 8 & No morphological difference between 7 and 8 days old larvae \\
\hline 9 & Yolk sac is found to be more reduced than that of 8 day old larvae \\
\hline 10 & Yolk sac is greatly reduced \\
\hline
\end{tabular}

"Newly hatched larva

Our findings on fertilisation (93\%) obtained by dry stripping from dead fishes of both sexes, where female and male died respectively before 45 and $25 \mathrm{~min}$, corroborate the findings of Malhotra et al. (1969) who obtained 90\% fertilisation by wet stripping of male and female of which one sex (either male or female) died $30 \mathrm{~min}$ earlier in two separate experiments. The confirmation of obtaining fertilised egg from dead brood fish, as observed in our study; obviously extended ample scope for conducting successful artificial fecundation of hilsa, particularly when both sexes in freely oozing condition are not available at a time in live condition from nature.

The results of the present study indicated that embryonic development and hatching (70 to $96 \%$ ) could be done at two different temperatures using estuarine, pond and tap water having wide ranges in the levels of different water quality parameters $(\mathrm{pH}$ - 7.3-7.8, DO - 7.95-8.4 $\mathrm{mg} \mathrm{l}^{-1}$, alkalinity - 94-255 $\mathrm{mg} \mathrm{l}^{-1}$, hardness - 138-246 $\mathrm{mg} \mathrm{l}^{-1}$, TDS - 183-855 $\mathrm{mg} \mathrm{l}^{-1}$, salinity - 0.13$0.59 \mathrm{~g} \mathrm{l}^{-1}$ and conductivity $\left.-258-1205 \mu \mathrm{S} \mathrm{cm}^{-1}\right)$. Malhotra et al. (1970) reported that the hatching rate of hilsa egg was $5-80 \%$ in river pool at $8.2-8.3 \mathrm{pH}$ and $6.4-8.0 \mathrm{mg} \mathrm{l}^{-1}$ DO and $15-30 \%$ in freshwater nursery pond at $6.4-8.0$ $\mathrm{mg} \mathrm{l}^{-1}$ DO. De and Sen (1986) and Sen et al. (1990) also reported that embryonic development and hatching was done in river water at 7.6-7.8 $\mathrm{pH}$ and 6.5-8.2 $\mathrm{mg} \mathrm{l}^{-1} \mathrm{DO}$, however, they have not studied the hatching rate.

It is well known that the river/estuary is the only ground where hilsa naturally breeds, eggs hatch and larvae grow. But there are limitations for conducting breeding, hatching and larval rearing under in situ riverine/estuarine condition in view of environmental calamities, pollution load and existence of diurnal tidal influx up to certain distance of the Hooghly Estuary. Similarly, use of estuarine water for hatching purpose in controlled condition is also found unfeasible due to limitations on the availability of suitable site where river water can be accessed. To overcome such condition, alternatively, egg incubation and hatching could be done by using pond water or tap water, pond water being most suitable for hatching as observed in the present study. Our results also showed that variations in water qualities and temperature used in the study did not have measurable effect on incubation period indicating that the normal embryonic developmental process is not altered in the range of temperatures tested in the present study $\left(22-28^{\circ} \mathrm{C}\right)$. This information might be a useful tool to undertake breeding and seed production of hilsa in diverse water environment for further evaluation.

Earlier workers have reported that during hatching of hilsa embryo, the tail of embryo moves vigorously, the egg membrane is ruptured and the embryo escapes out of the egg membrane (Jones and Menon, 1951; De and Sen, 1986). Our observations on hatching process of hilsa embryo indicated that rupturing of egg membrane was not done by vigorous movement of the embryo as the embryo did not move vigorously at this stage. Probably the folded caudal fin of embryo exerted pressure over egg shell to move the body slowly in forward direction and finally the head region ruptured the egg membrane to escape the larva from the egg.

During hatching, in several other teleost fish embryos, the hatching gland cells of embryo secretes proteolytic 


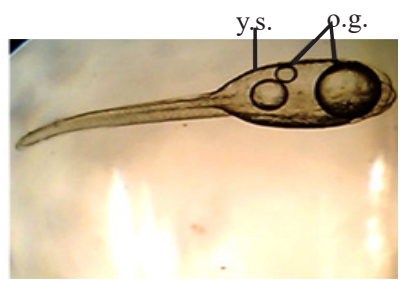

(a)

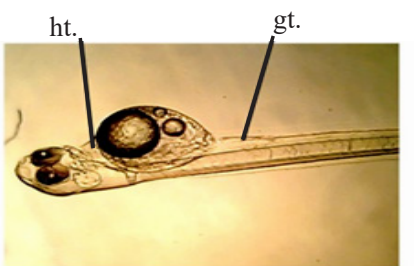

(e)

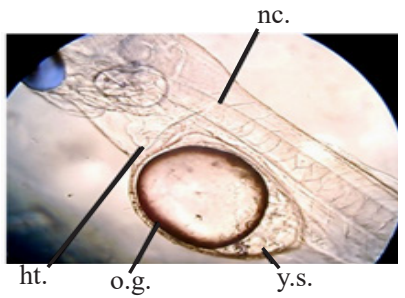

(i)

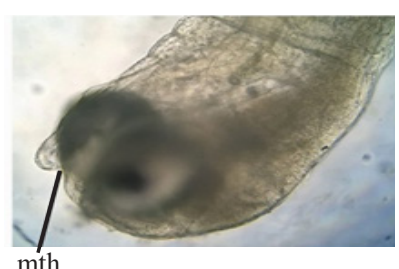

(m)

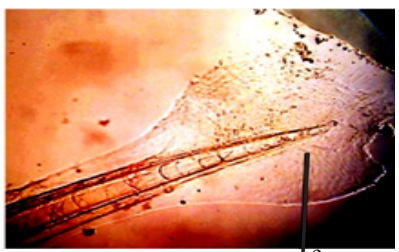

(q)

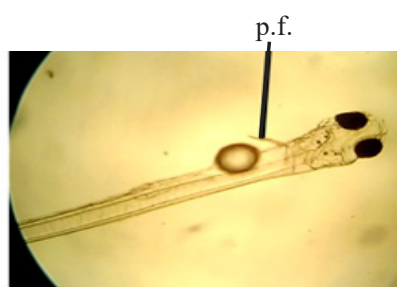

(u)

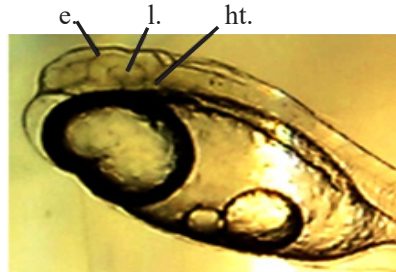

(b)

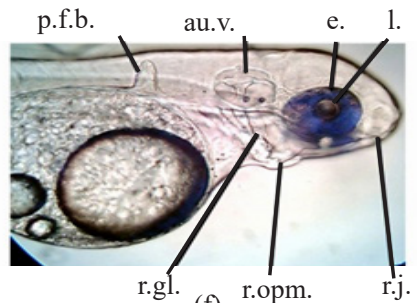

(f)

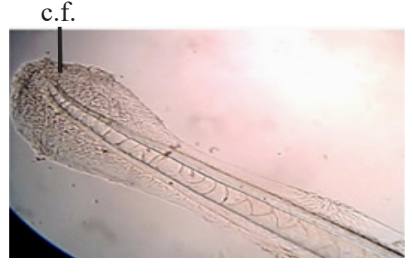

(j)

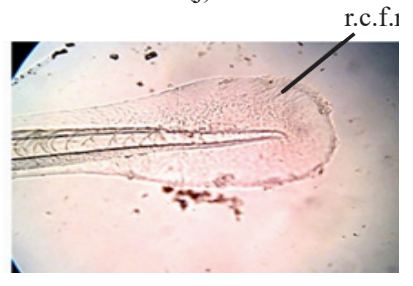

(n)

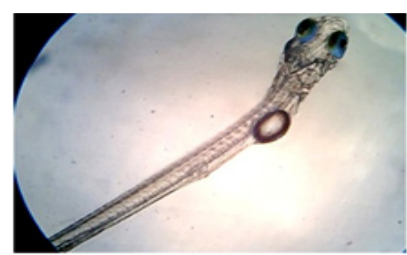

(r)

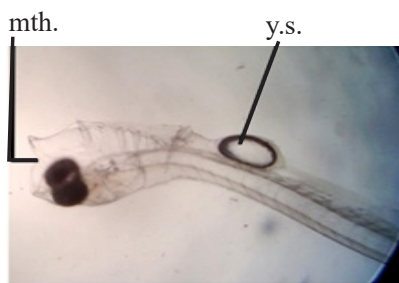

(v)

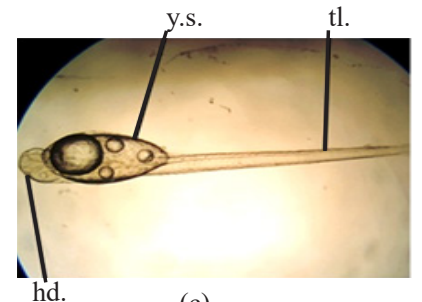

(c)

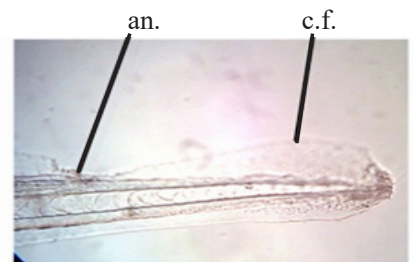

(g)

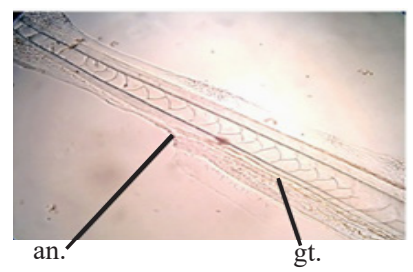

(k)

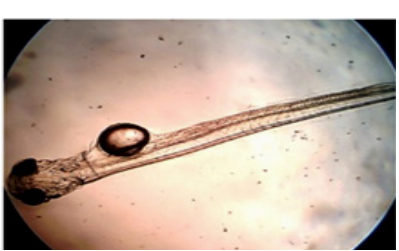

(o)

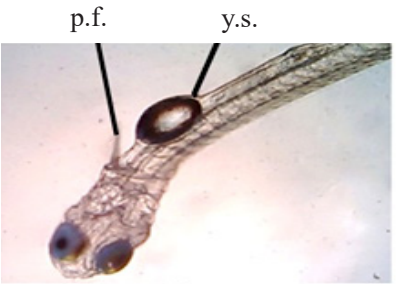

(s)

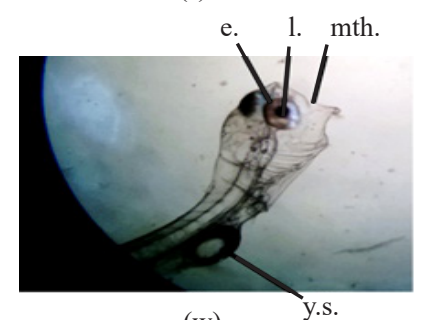

(w)

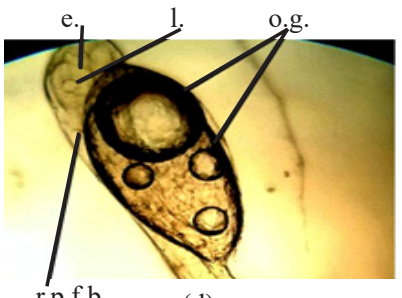

(d)

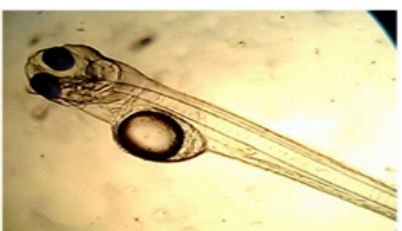

(h)

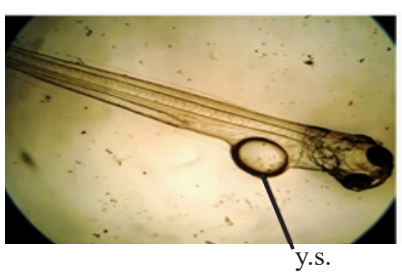

(1)

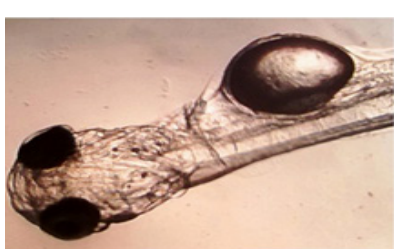

(p)

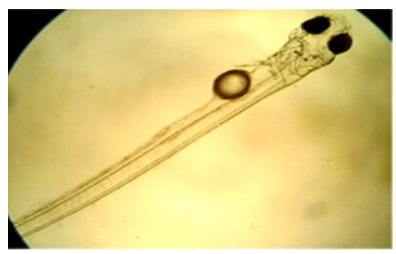

(t)

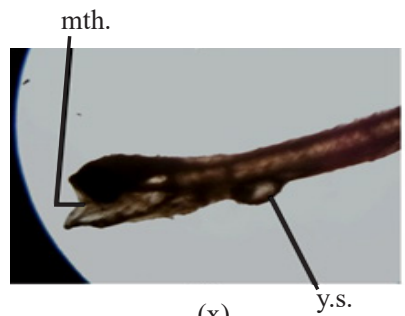

(x)

Fig. 2. Larval developmental stages (0-10 d old) of hilsa (Tenualosa ilisha). a - newly hatched larva (0-d old); b - anterior portion of 0-d old larva; c - 1-d old larva; $\mathrm{d}$ - anterior portion of 1-d old larva; e - 2-d old larva; f - anterior portion of 2-d old larva; $\mathrm{g}$ - posterior portion of 2-d old larva; $\mathrm{h}$ - 3-d old larva; i - anterior portion of 3-d old larva; $\mathrm{j}$ - caudal fin without fin ray of 3-d old larva; $\mathrm{k}$ - posterior portion of 3-d old larva; 1 - 4-d old larva; $\mathrm{m}$ - distinctly formed mouth of 4-d old larva; $\mathrm{n}$ - caudal fin with rudiments of fin rays of 4-d old larva; o - 5-d old larva; $\mathrm{p}$ - anterior portion of 5-d old larva; q - caudal fin with rudiments of fin rays of 5-d old larva; $r$ - 6-d old larva; $s$ - anterior portion of 6-d old larva; $t$ - 7-d old larva; $u$ - anterior portion of 7-d old larva; $v$ - anterior portion with yolk sac of 8-d old larva; w - anterior portion with yolk sac of 9-d old larva; $\mathrm{x}$ - anterior portion with yolk sac of 10-d old larva (an. - anus; au.v. - auditory vesicle; c.f. - caudal fin; e. - eye; gt. gut; hd. - head; ht. - heart; 1. - lens; mth. - mouth; nc - notochord; o.g. - oil globule; p.f. - pectoral fin; p.f.b. - pectoral fin bud; r.c.f.r. - rudiment of caudal fin ray; r.gl. - rudiment of gills; r.j. - rudiment of jaw; r.opm. - rudiment of operculum; r.p.f.b. - rudiment of pectoral fin bud; tl. - tail; y.s. - yolk sac) 


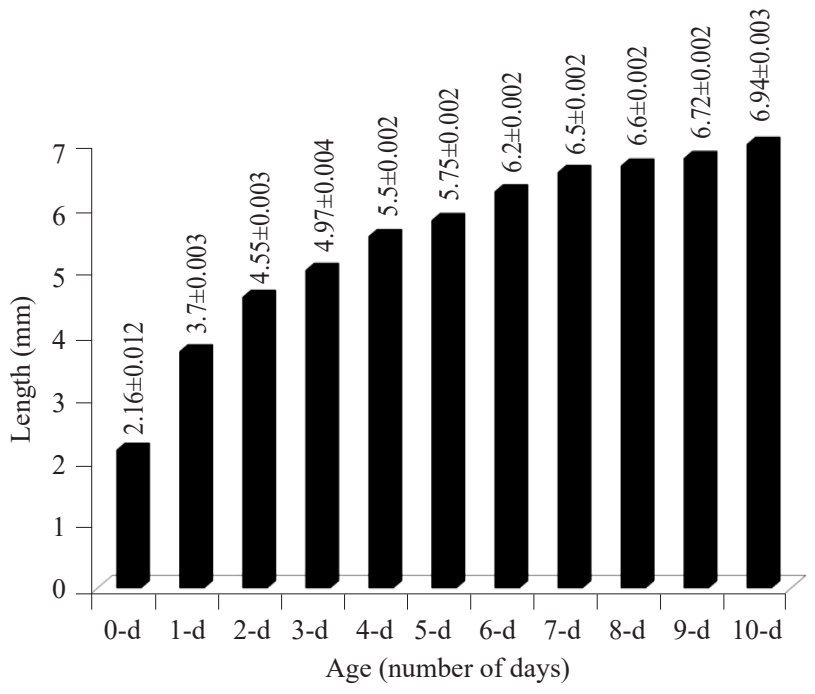

Fig. 3. Larval length of hilsa (Tenualosa ilisha) up to 10 days of age. Values are expressed as mean $(n=30) \pm S E$

hatching enzyme, the chorionase (Iuchi and Yamagami, 1976; Yamamoto et al. 1979; Yamagami 1981) which digests the scleroprotein of the inner layer of chorion, the zona radiate interna. This is followed by rupturing of the zona radiate externa by the vigorous movements of embryo as well as hitting the egg membrane by its head as reported in medaka Oryzias latipes (Yamamoto and Yamagami 1975). The role of hatching enzyme during hatching remains to be investigated in hilsa where the egg membrane is single layered as found in this study and also reported by others (Jones and Menon, 1951; De and Sen, 1986).
Table 5 presents comparison of the observation on characteristics of egg, embryo and larva of hilsa made in the present study with that of other authors. The time of formation of different organs in the embryo during embryonic development before hatching as reported by Jones and Menon (1951), Motwani et al. (1957) and Karamchandani (1961) probably fails to explain the exact time, since they have studied the eggs collected from nature where the exact time of fertilisation are not known. The diameter of fully swelled fertilised egg did not show marked differences as reported by others. The segmented yolk and single layered egg membrane as reported by others has been confirmed by microscopic observation. The double layered egg membrane as reported by Kulkarni (1950) and Motwani et al. (1957), might be due to contraction and splitting of membrane into two layers as reported by Jones and Menon (1951) in the dead embryo. The difference in the time of appearance of blastodermal cap, morula stage, germ ring, embryonic shield, head and tail bud, heart, optic vesicle, lenses and pigment in eye, auditory vesicle, pectoral fin buds, caudal fin lobe, rudimentary caudal fin rays, gut, anus, twitching movement of embryo and length of newly hatched larvae in the present study with that of other workers might be due to the differences in the qualities of water including temperature. We observed the movement of mouth in 4-day old larvae which could be considered as critical stage for first feeding larvae for their survival.

From this study it is concluded that hilsa eggs can be hatched using estuarine water, pond water and tap water having wide ranges of water quality parameters. The basic information on the artificial fecundation and hatching

Table 5. Comparison of the observations on the characteristics of egg, embryo and larva of hilsa made in the present study with that of other authors

\begin{tabular}{|c|c|c|c|c|}
\hline \multicolumn{2}{|c|}{ Parameters } & Observation in present study & Observation reported by others & Authors \\
\hline \multicolumn{5}{|l|}{ Egg } \\
\hline & \multirow{5}{*}{$\begin{array}{l}\text { Diameter of fully swelled } \\
\text { fertilised egg }\end{array}$} & \multirow[t]{5}{*}{$2.10 \mathrm{~mm}$} & $2.02 \mathrm{~mm}$ & De and Sen (1986) \\
\hline & & & $2.0 \mathrm{~mm}$ & Jones and Menon (1951) \\
\hline & & & $2.1-2.3 \mathrm{~mm}$ & Kulkarni (1950) \\
\hline & & & $2.03-2.05 \mathrm{~mm}$ & Motwani et al. (1957) \\
\hline & & & $1.8 \mathrm{~mm}$ & Southwell and Prasad (1918) \\
\hline \multirow{2}{*}{\multicolumn{2}{|c|}{ (ii) Nature of egg yolk }} & \multirow[t]{2}{*}{ Segmented } & Segmented & $\begin{array}{l}\text { De and Sen (1986); Jones and Menon } \\
\text { (1951); Motwani et al. (1957) }\end{array}$ \\
\hline & & & Not segmented & Kulkarni (1950) \\
\hline \multirow{2}{*}{\multicolumn{2}{|c|}{ (iii) Nature of egg membrane }} & \multirow[t]{2}{*}{ Single layered } & Single layered & $\begin{array}{l}\text { De and Sen (1986); Jones and Menon } \\
\text { (1951) }\end{array}$ \\
\hline & & & Double layered & Kulkarni (1950); Motwani et al. (1957) \\
\hline \multicolumn{5}{|c|}{ Development upto gastrula stage } \\
\hline \multirow[t]{2}{*}{ (i) } & \multirow{2}{*}{$\begin{array}{l}\text { Appearance of blastodermal } \\
\text { cap }\end{array}$} & \multirow[t]{2}{*}{ After $2 \mathrm{~h}$ of fertilisation } & After 2 h 30 min of fertilisation & De and Sen (1986) \\
\hline & & & After $30 \mathrm{~min}-1 \mathrm{~h}$ of fertilisation & Jones and Menon (1951) \\
\hline
\end{tabular}




\begin{tabular}{|c|c|c|c|}
\hline (ii) Formation of morula stage & After $3 \mathrm{~h}$ of fertilisation & After $3 \mathrm{~h} 30$ min of fertilisation & De and Sen (1986) \\
\hline (iii) Initiation of blastula & After $4 \mathrm{~h}$ of fertilisation & Not reported & \\
\hline (iv) Time period of gastrulation & $5-11 \mathrm{~h}$ of fertilisation & Not reported & \\
\hline (v) Visibility of germ ring & After $7 \mathrm{~h}$ of fertilisation & After $6 \mathrm{~h} 30 \mathrm{~min}$ & De and Sen (1986) \\
\hline & & At $4 \mathrm{~h}$ of fertilisation & Jones and Menon (1951) \\
\hline $\begin{array}{l}\text { (vi) Appearance of embryonic } \\
\text { shield }\end{array}$ & After $9 \mathrm{~h}$ of fertilisation & After $8 \mathrm{~h}$ of fertilisation & Kulkarni (1950) \\
\hline \multicolumn{4}{|l|}{ Head and tail } \\
\hline \multirow{3}{*}{$\begin{array}{l}\text { (i) Appearance of head and } \\
\text { tail bud }\end{array}$} & \multirow[t]{3}{*}{ After $11 \mathrm{~h}$ of fertilisation } & After $10 \mathrm{~h} 15$ min of fertilisation & De and Sen (1986) \\
\hline & & After $12 \mathrm{~h}$ of fertilisation & Kulkarni, (1950) \\
\hline & & $\begin{array}{l}\text { Head appeared at } 7-9 \mathrm{~h} \text { of } \\
\text { fertilisation and caudal end } \\
\text { appeared at } 15 \mathrm{~h} \text { of fertilisation }\end{array}$ & Jones and Menon (1951) \\
\hline \multicolumn{4}{|l|}{ Heart } \\
\hline \multirow[t]{3}{*}{ (i) First appearance of heart } & \multirow{3}{*}{$\begin{array}{l}\text { After } 19 \mathrm{~h} \text { of fertilisation in } \\
\text { the embryo just before } \\
\text { hatching }\end{array}$} & At 3-5 $\mathrm{h}$ before hatching & Motwani et al. (1957) \\
\hline & & In 1-day old larvae & De and Sen (1986); Kulkarni (1950) \\
\hline & & After 16-19 h of fertilisation & Jones and Menon (1951) \\
\hline \multicolumn{4}{|l|}{ Sensory organs } \\
\hline \multirow[t]{4}{*}{ (i) Appearance of optic vesicle } & \multirow[t]{4}{*}{ After $15 \mathrm{~h}$ of fertilisation } & After $10 \mathrm{~h} 15$ min of fertilisation & De and Sen (1986) \\
\hline & & After $7-9 \mathrm{~h}$ of fertilisation & Jones and Menon (1951) \\
\hline & & In newly hatched larva & Kulkarni (1950) \\
\hline & & $\begin{array}{l}\text { In embryonic stage (exact time is } \\
\text { not reported) }\end{array}$ & Karamchandani (1961) \\
\hline \multirow[t]{3}{*}{$\begin{array}{l}\text { (ii) Appearance of lenses and } \\
\text { pigment in eye }\end{array}$} & \multirow{3}{*}{$\begin{array}{l}\text { Lenses appeared in newly } \\
\text { hatched larvae and pigment } \\
\text { appeared in 2-day old larvae }\end{array}$} & $\begin{array}{l}\text { Both lens and few pigment cells } \\
\text { appeared in 2-day old larvae }\end{array}$ & De and Sen (1986) \\
\hline & & $\begin{array}{l}\text { Black pigment appeared in 1-day } \\
\text { larvae }\end{array}$ & Jones and Menon (1951) \\
\hline & & $\begin{array}{l}\text { Black pigment appeared in 2-day } \\
\text { old larvae }\end{array}$ & Kulkarni (1950) \\
\hline \multirow{4}{*}{$\begin{array}{l}\text { (iii) Appearance of auditory } \\
\text { vesicle }\end{array}$} & \multirow[t]{4}{*}{ After $16 \mathrm{~h}$ of fertilisation } & After $13 \mathrm{~h}$ of fertilisation & De and Sen (1986) \\
\hline & & After $15 \mathrm{~h}$ of fertilisation & Jones and Menon (1951) \\
\hline & & In 1-day old larva & Kulkarni (1950) \\
\hline & & At 6-9 $\mathrm{h}$ before hatching & Motwani et al. (1957) \\
\hline \multicolumn{4}{|l|}{ Locomotary organs } \\
\hline \multirow[t]{2}{*}{ (i) Formation of pectoral fin buds } & \multirow[t]{2}{*}{ In 1-day old larvae } & In 1-day old larvae & De and Sen (1986) \\
\hline & & In 2-day old larvae & Jones and Menon (1951) \\
\hline \multirow[t]{2}{*}{ (ii) Formation of caudal fin lobe } & \multirow[t]{2}{*}{ In 1-day old larvae } & In 1-day old larvae & $\begin{array}{l}\text { Jones and Menon (1951); Kulkarni } \\
\text { (1950) }\end{array}$ \\
\hline & & In newly hatched larvae & De and Sen (1986) \\
\hline \multirow{2}{*}{$\begin{array}{l}\text { (iii) Formation of rudimentary } \\
\text { caudal fin rays }\end{array}$} & \multirow[t]{2}{*}{ In 4-day old larvae } & In 5-day old larvae. & De and Sen (1986) \\
\hline & & $\begin{array}{l}\text { Caudal fin rays are not found in } \\
\text { 4-day old larvae }\end{array}$ & Jones and Menon (1951) \\
\hline \multicolumn{4}{|l|}{ Digestive and respiratory organs } \\
\hline \multirow[t]{3}{*}{ (i) Formation of gut and anus } & \multirow[t]{3}{*}{ In 2-day old larvae } & In 2-day old larvae & Kulkarni (1950) \\
\hline & & $\begin{array}{l}\text { Alimentary canal appears as a fine } \\
\text { tube in 2-day old larvae (time of } \\
\text { anus formation is not reported) }\end{array}$ & Jones and Menon (1951) \\
\hline & & $\begin{array}{l}\text { Posterior portion of alimentary } \\
\text { canal was visible as a faint straight } \\
\text { tube and anal opening was not } \\
\text { distinct though position was } \\
\text { identified in 1-day old larvae. }\end{array}$ & De and Sen (1986) \\
\hline
\end{tabular}




\begin{tabular}{|c|c|c|c|}
\hline $\begin{array}{l}\text { (ii) Indication of mouth and jaw } \\
\text { formation }\end{array}$ & In 2-day old larvae & In 2-day old larvae & $\begin{array}{l}\text { De and Sen (1986); Jones and Menon } \\
\text { (1951) }\end{array}$ \\
\hline $\begin{array}{l}\text { (iii) Appearance of distinctly } \\
\text { formed mouth and its } \\
\text { movement }\end{array}$ & In 4-day old larvae & $\begin{array}{l}\text { In 4-day old larvae (movement of } \\
\text { mouth is not reported) }\end{array}$ & Jones and Menon (1951) \\
\hline $\begin{array}{l}\text { (iv) Rudiments of gills, } \\
\text { operculum and opercular } \\
\text { movement }\end{array}$ & In 2-day old larvae & $\begin{array}{l}\text { In 2-day old larvae (opercular } \\
\text { movement is not reported) }\end{array}$ & Jones and Menon (1951) \\
\hline \multicolumn{4}{|l|}{ Embryonic movement } \\
\hline \multirow{3}{*}{$\begin{array}{l}\text { (i) Initiation of twitching } \\
\text { movement }\end{array}$} & \multirow[t]{3}{*}{ After $17 \mathrm{~h}$ of fertilisation } & After $16 \mathrm{~h}$ of fertilisation & De and Sen (1986) \\
\hline & & After $16-19 \mathrm{~h}$ of fertilisation & Jones and Menon (1951) \\
\hline & & After $15 \mathrm{~h}$ of fertilisation & Kulkarni (1950) \\
\hline \multicolumn{4}{|l|}{ Larval length } \\
\hline \multirow{6}{*}{$\begin{array}{l}\text { (i) Length of newly hatched } \\
\text { larvae }\end{array}$} & \multirow[t]{6}{*}{$2.16 \mathrm{~mm}$} & $2.41 \mathrm{~mm}$ & De and Sen (1986) \\
\hline & & $2.3 \mathrm{~mm}$ & Jones and Menon (1951) \\
\hline & & $2.65 \mathrm{~mm}$ & Karamchandani (1961) \\
\hline & & $3.1 \mathrm{~mm}$ & Kulkarni (1950) \\
\hline & & $2.5-2.55 \mathrm{~mm}$ & Motwani et al. (1957) \\
\hline & & $2.37 \mathrm{~mm}$ & Sen et al. (1990) \\
\hline
\end{tabular}

under different water qualities might be useful for mass production of hilsa seed necessary for advancement of hilsa culture in future. The characteristics of embryonic as well as larval developmental stages of hilsa in the present study may help in recognising the similar stages available in the natural environment and therefore, time of fertilisation, age of larva, spawning ground and spawning season in the natural habitat can be evaluated which would help in implementation of specific conservation methods for restoration of normal population density of hilsa.

\section{Acknowledgements}

The authors wish to express their gratitude to the Director, ICAR-CIFA, Bhubaneswar for encouragement and providing necessary facilities. The authors deeply acknowledge Dr. S. Ayyappan, former DG, ICAR for his keen interest, constant guidance and all kinds of support. Financial support received from NASF, ICAR, New Delhi under the project "Stock characterisation, captive breeding, seed production and culture of hilsa (Tenualosa ilisha)" is duly acknowledged. The authors also thank Dr V. R. Suresh (PI of the project), ICARCIFRI, Barrackpore for unstinted cooperation during the study period.

\section{References}

APHA 1995. Standard methods for the examination of water and wastewater, $19^{\text {th }}$ edn. American Public Health Association and Water Pollution Control Federation, Washington, USA.

De, D. K. and Sen, P. R. 1986. Observations on the embryonic and early larval development of Indian shad, Tenualosa ilisha (Ham.). J. Inland Fish. Soc. India, 18: 1-12.
DADF 2014. Handbook on Fisheries Statistics 2014. Department of Animal Husbandry, Dairying and Fisheries, Ministry of Agriculture, Government of India, New Delhi.

Iuchi, I. and Yamagami, K. 1976. Induction of a precocious secretion of the hatching enzyme in the rainbow trout embryo by electric stimulation. Zoological Magazine, 85: 273-277.

Jafri, S. I. H. and Melvin, G. D. 1988. Annotated bibiliography of the Indian shad, Tenualosa ilisha (Hamilton) (Clupeidae:Teleostei). IDRC, Canada.

Jones, S. and Menon, P. M. G. 1951. Observations on the life history of the Indian Shad, Hilsa ilisha (Hamilton). Proc. Indian Acad. Sci., 31: 101-125.

Karamchandani, S. J. 1961. On the location of spawning grounds of Indian shad, Hilsa ilisha (Hamilton) in freshwater regions of the Narbada River. Curr. Sci., 30: 373-375.

Kulkarni, C. V. 1950. Breeding habits, eggs and early life history of the Indian shad, Hilsa ilisha (Hamilton) in the Narbada River. Proceedings of the National Institute of Sciences in India, B16: 169-176.

Lal, K. K., Punia, P. and Ponniah, A. G. 1999. Extender composition for cryopreservation of Tenualosa ilisha spermatozoa with specific reference to inhibition of motility. Indian J. Fish., 46: 337-343.

Malhotra, J. C., Mathur, P. K., Kamal, M. V. and Mehrotra, S. N. 1970. Observations on the hatching of fertilised eggs of Hilsa ilisha (Hamilton) in confined freshwaters. Curr. Sci., 39: 538-539.

Malhotra, J. C., Mathur, P. K., Kamal, M. Y., Chandra, R. and Desai, V. R. 1969. Successful artificial propagation of Hilsa ilisha (Hamilton) near Allahabad. Curr. Sci., 38: 429-430. 
Mathur, P. K., Malhotra, J. C., Mehrotra, S. N. and Shah, K. K. 1974. Experiments on the nursery rearings of spawn of Hilsa ilisha (Hamilton) in freshwater ponds. J. Inland Fish. Soc. India, 6: 205-210.

Motwani, M. P., Jhingran, V. G. and Karamchandani, S. J. 1957. On the breeding of the Indian shad, Hilsa ilisha (Hamilton) in freshwaters. Sci. Cult., 23: 47-48.

Panicker, P. K. R., Mod, K. G., Patel, A. J. and Joykutty, T. P. 1982. Hilsa thrives in Vallabhasagar. Fishing Chimes, 2: 13-14.

Pillay, S. R. and Rosa, H. 1963. Synopsis of biological data on hilsa, Hilsa ilisha (Hamilton, 1822). FAO Fish. Synop., 25: $61 \mathrm{pp}$.

Sen, P. R., De, D. K. and Nath, D. 1990. Experiments on artificial propagation of Hilsa, Tenualosa ilisha (Ham.). Indian J. Fish., 37: 159-162.
Southwell, T. and Prashad, B. 1918. On hilsa investigations in Bengal, Bihar and Orissa. Bulletin of the Department of Fisheries, Bengal, Bihar and Orissa, 11: 1-12.

Yamagami, K. 1981. Mechanism of hatching in fish: secretion of hatching enzyme and enzymatic choriolysis. Am. Zool., 21: 459-471. DOI: $10.1093 / \mathrm{icb} / 21.2 .459$.

Yamamoto, M., Iuchi, I. and Yamagami, K. 1979. Ultrastructural changes of the teleostean hatching gland cell during natural and electrically induced precocious secretion. Dev. Biol., 68: 162-174. doi.org/10.1016/0012-1606(79)90251-3.

Yamamoto, M. and Yamagami, K. 1975. Electron microscopic studies on choriolysis by the hatching enzyme of the teleost, Oryzias latipes. Dev. Biol., 43: 313-321. doi. org/10.1016/0012-1606(75)90030-5. 